\title{
Compost Quality and Markets Are Pivotal for Sustainability in Circular Food-Nutrient Systems: A Case Study of Sri Lanka
}

\author{
Eric D. Roy ${ }^{1,2,3 *}$, Mohamed Esham ${ }^{4}$, Nilanthi Jayathilake ${ }^{5}$, Miriam Otoo ${ }^{6}$, \\ Christopher Koliba ${ }^{3,7}$, Isuru B. Wijethunga ${ }^{8}$ and Maya J. Fein-Cole ${ }^{1}$
}

\begin{abstract}
${ }^{1}$ Rubenstein School of Environment and Natural Resources, University of Vermont, Burlington, VT, United States, ${ }^{2}$ Department of Civil and Environmental Engineering, University of Vermont, Burlington, VT, United States, ${ }^{3}$ Gund Institute for Environment, University of Vermont, Burlington, VT, United States, ${ }^{4}$ Department of Agribusiness Management, Sabaragamuwa University of Sri Lanka, Belihuloya, Sri Lanka, ${ }^{5}$ International Water Management Institute, Colombo, Sri Lanka, ${ }^{6}$ Tetra Tech, ARD, Arlington, VA, United States, ${ }^{7}$ Department of Community Development and Applied Economics, University of Vermont, Burlington, VT, United States, ${ }^{8}$ Department of Export Agriculture, Sabaragamuwa University of Sri Lanka, Belihuloya, Sri Lanka
\end{abstract}

OPEN ACCESS

Edited by: José Martinez, Institut National de Recherche pour l'Agriculture, l'Alimentation et l'Environnement (INRAE), France

Reviewed by:

Harald Menzi, Federal Office for the Environment, Switzerland

M. A. Bustamante,

Miguel Hernández University of Elche, Spain

*Correspondence: Eric D. Roy eroy4@uvm.edu

Specialty section: This article was submitted to Waste Management in Agroecosystems,

a section of the journal Frontiers in Sustainable Food Systems

Received: 27 July 2021 Accepted: 19 October 2021 Published: 19 November 2021

Citation:

Roy ED, Esham M, Jayathilake N, Otoo M, Koliba C, Wijethunga IB and Fein-Cole MJ (2021) Compost Quality and Markets Are Pivotal for Sustainability in Circular Food-Nutrient Systems: A Case Study of Sri Lanka. Front. Sustain. Food Syst. 5:748391. doi: 10.3389/fsufs.2021.748391
Sustainable management of municipal solid waste (MSW) is a critical issue around the world, especially in South Asia where waste generation is expected to double by 2050. Closing the food-nutrient cycle through composting biodegradable MSW has the potential to meet human needs, including sanitation and food security, while protecting the environment. We use an interdisciplinary case study approach including systems thinking to assess Sri Lanka's national MSW composting system, which primarily receives residential and commercial food waste. We embed quantitative compost quality analysis and interviews at 20 composting facilities within a broader qualitative assessment informed by $\sim 60$ stakeholders in total. This approach yields insights on how institutional, economic, social, and biophysical aspects of the system are interrelated, and how challenges and solutions can create undesirable and desirable cascading effects, respectively. Such dynamics can create risks of composting facility failure and unintended consequences, diminishing the chances of achieving a sustainable circular food-nutrient system. Compost quality, which was variable, plays a pivotal role within the system - a function of program design and implementation, as well as a determinant of value capture in a circular economy. We make several recommendations to inform future efforts to sustainably manage biodegradable MSW using composting, drawing on our case study of Sri Lanka and prior case studies from other nations. Key among these is the need for increased emphasis on compost product quality and markets in policy and program design and implementation. Targeted measures are needed to improve waste separation, boost compost quality, effectively use compost standards, encourage compost market development, ringfence the revenues generated at municipal compost plants, and identify efficient modes of compost distribution. Such measures require adequate space and infrastructure for composting, resource investment, local expertise to guide effective system management, strong links with the agriculture sector, and continued political support.

Keywords: compost, systems thinking, case study, food waste, municipal solid waste (MSW), circular economy 


\section{INTRODUCTION}

Around the world, economic development, population growth, and urbanization have been linked to increases in per capita generation of solid waste, along with logistical challenges created by the increased concentration of waste in cities (Kaza et al., 2018). Poor management of this waste causes numerous environmental and human health problems, including degradation of aquatic ecosystems and water quality, impedance of stormwater flows causing localized flooding, disease transmission, respiratory problems linked to burning of waste, harmful effects to animals, and diminished tourism (Kaza et al., 2018). Achieving sustainable solid waste management remains a challenge across nations, including those in Asia, due to a combination of institutional, economic, social, and technical factors (Idris et al., 2004; Pariatamby and Fauziah, 2014; Kaza et al., 2018; Fernando, 2019). Waste generation in South Asia, which accounted for $17 \%$ of global waste generation in 2016, is projected to approximately double by 2050, reaching 661 million tons per year (Kaza et al., 2018). This expected magnitude of increase in waste generation is second only to Sub-Saharan Africa, and therefore current and future efforts to improve solid waste management in South Asia are critically important.

Within South Asia, Sri Lanka is an illustrative case. Waste collection and disposal in Sri Lanka has become a serious problem in recent decades due to increasing waste generation coupled with a lack of widespread, well-resourced waste management infrastructure, and the consequent open dumping and burning of discarded materials (van Zon and Siriwardena, 2000; Basnayake and Visvanathan, 2014; Fernando, 2019). Numerous programs have been established in response, including National Policy on Solid Waste Management (2007) and the Ministry of Environment and Natural Resources-led Pilisaru National Solid Waste Management Program (2008) (Basnayake and Visvanathan, 2014; JICA, 2016; Fernando, 2019). The responsibility of solid waste management in Sri Lanka ultimately is in the hands of local government entities, including municipal councils, urban councils, and Pradeshiya Sabhas, which rely on budgetary allocations from the central government, along with tax and non-tax revenues (Basnayake and Visvanathan, 2014; Fernando, 2019).

More than $60 \%$ of the municipal solid waste (MSW) generated in Sri Lanka is organic in nature and thus biodegradable, which is comparable to other nations in Asia including India, Thailand, and China (Basnayake and Visvanathan, 2014). Sri Lanka's Pilisaru Program included the establishment of $>100$ composting facilities around the nation to process biodegradable MSW (Figure 1; JICA, 2016). Composting is an attractive strategy for managing biodegradable MSW in Sri Lanka and elsewhere, with potential co-benefits including nutrient recycling to alleviate need for synthetic fertilizers, soil improvement, and climate mitigation (e.g., reduction of methane generation associated with decomposition of biodegradable waste in landfills and dump sites) (Samarasinha et al., 2015; Cordell et al., 2021). Closing of the food-nutrient cycle, through composting and other resource recovery and reuse strategies, offers the potential to help meet

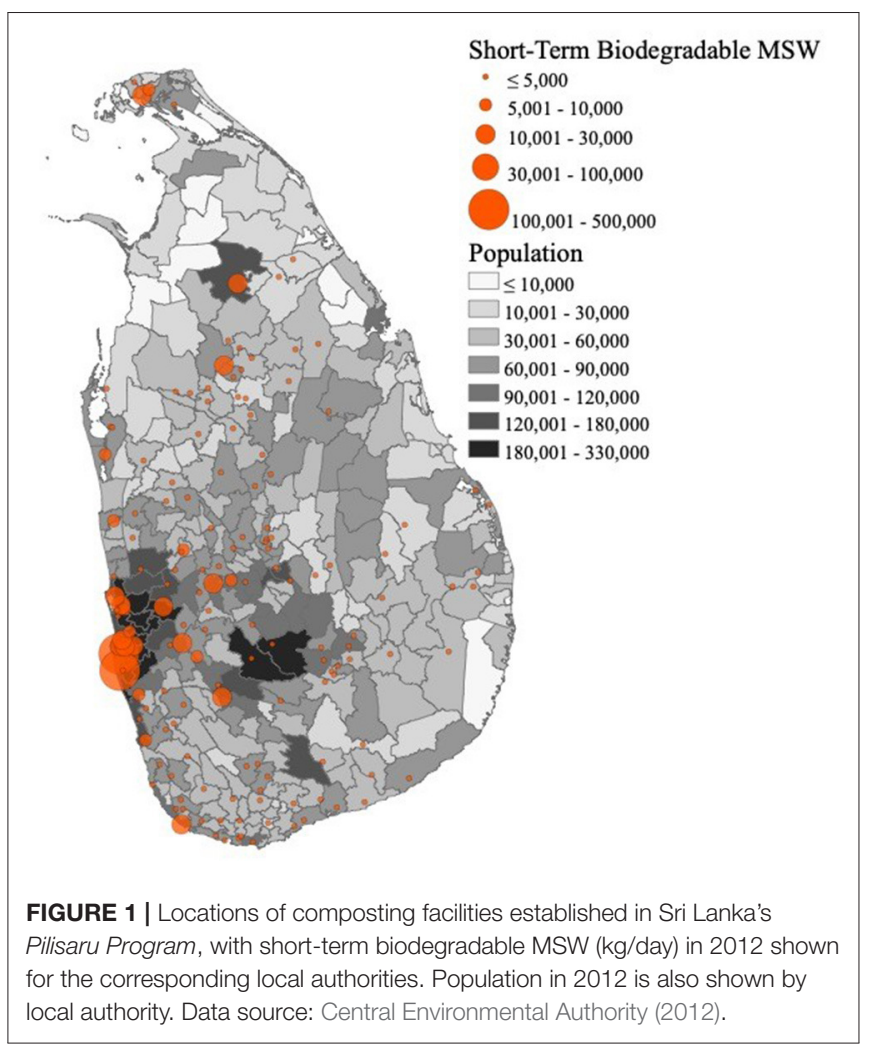

human needs, including sanitation and food security, while protecting the environment (Roy, 2017; Hanjra et al., 2018; Otoo and Drechsel, 2018). Furthermore, the National Adaptation Plan for Climate Change in Sri Lanka calls for increased use of organic matter to improve soil quality (Climate Change Secretariat, 2016). Most recently, the Sri Lankan government has restricted and banned the import of fertilizers and agrochemicals, with some observers cautioning that in the short term Sri Lanka does not have the capability to expand organic fertilizer production capacity sufficiently to meet current fertilizer use requirements (Beillard and Galappattige, 2021).

It has been estimated that establishing facilities to recycle organic waste in Sri Lanka could decrease total waste management and chemical fertilizer costs by US $\$ 191$ million to US\$357 million, depending on the level of inter-provincial trade (Bekchanov and Mirzabaev, 2018). However, contamination of MSW-derived compost is a concern, with potential contaminants including pathogens, microplastics, potentially toxic elements, antibiotic resistance determinants, and other inorganic and organic pollutants, several of which remain infrequently measured (Dandeniya and Caucci, 2020; Gui et al., 2021). Compost quality, a concept which includes maturity and stability, physical and chemical properties, and pollutants, is inherent to the definition of compost: "the stabilized and sanitized product of composting, which has undergone an initial, rapid stage of decomposition, is beneficial to plant growth and has certain humic characteristics" (Bernal et al., 2009, 2017). Compost quality standards are needed to address specific 


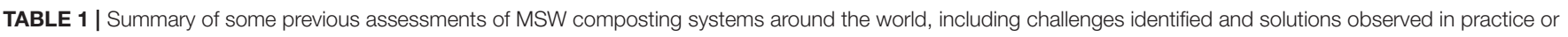
suggested.

\begin{tabular}{|c|c|c|c|}
\hline Location & Challenges identified & Solutions observed in practice (o) or suggested (s) & Reference \\
\hline Canada & $\begin{array}{l}\text { - Lack of a shared vision about the role of government, } \\
\text { private sector, and citizens, in producing high quality } \\
\text { compost } \\
\text { - Cultural inertia, lack of knowledge, and lack of }\end{array}$ & $\begin{array}{l}\text { - Expansion of urban agriculture connected to waste } \\
\text { management activities (s) } \\
\text { - Linking key stakeholders to co-create shared visions } \\
\text { about how to produce high quality compost (s) }\end{array}$ & $\begin{array}{l}\text { Metson and Bennett, } \\
2015\end{array}$ \\
\hline
\end{tabular}
infrastructure

- Limited space for urban agriculture and training for use of compost

Catalonia

- Roadside food waste collection containers are unpopular due to space requirements, uncleanliness, and odors

France

- Poor compost quality, including heavy metals and glass/plastic particles too small to be screened out (both linked to use of hammer mills or shredders prior to composting)

Germany $\quad$ - Long collection intervals have led to some protests from citizens fearing hygienic issues and bad smells

Ghana

- The effective demand for compost for agricultural purposes is marginal and limited by farmers' transport costs

- Compost must be low-cost but nutrient-rich to compete with abundant and cheap poultry manure

Greece $\quad$ Poor and variable compost quality

Guatemala $\quad$ Entrepreneurs lacked knowledge of total inputs needed/used for compost operation and effective financial record keeping

- Net profits fell when inexpensive unskilled labor was used and when an operation's infrastructure deterred access to transport

Italy

- Need for a user friendly (low odor) and affordable collection system

Malaysia $\quad$ - Lack of public acceptance

- Difficult for households to obtain high C:N materials (bulking agents)

- Unpleasant odor in household applications

- Improper waste sorting

Palestine $\quad$ Medium quality compost due to partial or non-compliance with some of the testing parameters

Saudi Arabia - Composts produced using food waste were incapable of improving the quality and fertility of sandy soils and the growth of crops, due to low organic matter, nutrient contents, and water holding capacity along with high moisture contents, nitrification index, and ammonia emissions

Taiwan

- Few facilities can gain profits due to small scale and low market value

United States

- Low anticipated use of curbside food waste pickup program in rural state

- Unwillingness to pay anything additional for food waste pickup in rural state
- Some municipalities have implemented door-to-door collection, achieving greater food waste diversion rates (o)

- Improved mechanical processing technology (o)

- Improved community sorting of waste (o)

- Most municipalities have moved to weekly bio-waste collections during warm season (o)

- Additional consideration of the demand of the construction sector can increase amount of organic MSW transformation and utilization (s)

- Public subsidies to support production of low-cost, nutrient rich compost (s)

- Establishment of quality assurance procedures and mechanisms (s)

- Development of EU compost quality standards to harmonize compost markets (s)

- Training programs for micro-enterprise development that include instruction on effective composting practices, recordkeeping, compost quality, and good business practices (s)

- Provision of information on total variable costs, total revenue, and consumer accessibility by Extension agents (s)

- To achieve high participation and diversion rates, most municipalities adjusted the food waste collection interval to twice per week, and four times per week in warm season for some locations (o)

- Increase in landfilling costs to establish financial viability for the composting system (s)

- Establishment of multi-actor partnerships (s)

- Attractive rewards for proper waste sorting (s)

- Promote compost use in agriculture and encourage its use through subsidies (s)

- Pursue optimized composting facilities using natural zeolites and biochar (s)

- Direct marketing can avoid distribution costs and improve net profits (o)

- A subsidy to compost producers is needed to expand the market demand (s)

- Compost product standards should be regulated (s)

- Greater investment in education and infrastructure for home composting in rural areas (s)
Meyer-Kohlstock et al., 2015

Meyer-Kohlstock et al., 2015

Meyer-Kohlstock et al., 2015

Danso et al., 2006

Lasardi et al., 2006

Silberg et al., 2013

Meyer-Kohlstock et al., 2015

Keng et al., 2020

Al-Sari et al., 2018

Waqas et al., 2017

Chen, 2016

Niles, 2020 
concerns and general skepticism among potential compost buyers to help ensure adequate product markets (Samarasinha et al., 2015; Fernando, 2019). Currently, Sri Lanka Standard SLS 1634:2019 includes specifications for compost made from MSW, including general physical, chemical, microbiological, and biological requirements, as well as limits for potentially toxic elements (Sri Lanka Standards Institution, 2019; Dandeniya and Caucci, 2020).

Multiple previous studies have assessed aspects of Sri Lanka's composting system for management of biodegradable MSW. Basnayake and Visvanathan (2014) suggested that composting efforts in Sri Lanka have failed due to poor compost quality, high operational costs, and lack of financing. Furthermore, others observed that nuisance odors, leachate pollution, and increased density of wild animals and flies have negatively affected perceptions of composting operations in some regions, leading to protests, lack of compost business development, and lack of effective compost use (Samarasinha et al., 2015; Dandeniya and Caucci, 2020). Fernando (2019) identified a large number of institutional, economic, and social factors that influence solid waste management in Sri Lanka, including numerous factors that are particularly relevant for biodegradable MSW. These include regulatory frameworks, finances, waste separation, markets, labor, and availability of technology (Fernando, 2019). Bekchanov and Mirzabaev (2018) suggest that successful implementation of wide-scale composting projects will require better accounting and planning in the waste management system, greater public awareness about waste-derived environmental pollution, and better working conditions and safety in this sector. Previous case studies in other nations around the world also provide valuable insights on composting systems within circular economy efforts, including challenges faced and proven or potential solutions (Table 1).

In this study, our objectives were to (1) build on existing assessments of Sri Lanka's national biodegradable MSW composting system using an interdisciplinary case study approach including systems thinking, and (2) inform future efforts to sustainably manage biodegradable MSW using composting within Sri Lanka and elsewhere.

\section{MATERIALS AND METHODS}

\section{Theoretical Framework}

We used a case study framework with embedded units of analysis (Yin, 2003). The case study framework is suitable for studying a contemporary waste management situation to which local "real-life" context is intrinsically linked and where the research team has little or no control (Metson and Bennett, 2015). We defined the main unit in our case study as the biodegradable MSW composting system of Sri Lanka, with emphasis on five districts in the southwest portion of the nation that collectively account for approximately three quarters of the shortterm biodegradable MSW available for composting nationwide (Central Environmental Authority, 2012). Furthermore, we examined multiple embedded units (i.e., 20 composting facilities) to generate data that are more convincing and investigate broader topics than focus on a single facility would allow (Yin, 2009).
Sri Lanka's national biodegradable MSW composting system (qualitative analysis)

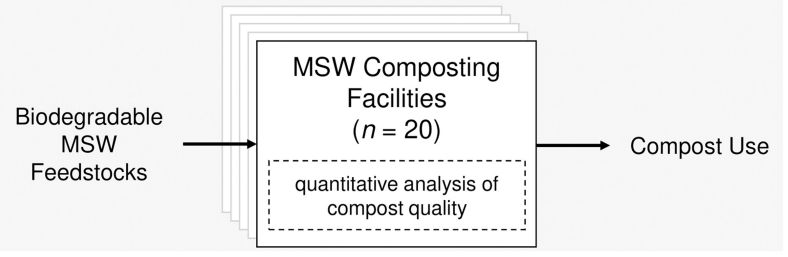

FIGURE 2 | Our case study framework with multiple embedded units and concurrent embedded design for data collection.

We used a mixed methods approach to collect data and elucidate key system features, challenges, and factors that support success. This approach largely conformed to a concurrent embedded design as defined by Creswell (2009), with quantitative compost quality analysis embedded within a broader qualitative case study assessment (Figure 2). However, the multiple components of this study did allow for some sequencing where findings in earlier research tasks informed later ones. Finally, we examined MSW composting systems in Sri Lanka using systems thinking (Meadows, 2008), guided in part by a recent application in the context of resource recovery and reuse (Nedelciu et al., 2019).

Our case study included the following elements: structured interviews with composting facility managers, compost quality analysis, and two stakeholder workshops. This study was determined to be exempt by the University of Vermont Institutional Review Board. The research information sheet, including survey questions and stakeholder discussion prompts, are provided in the Supplementary Materials.

\section{Structured Interviews With Composting Facility Managers}

We interviewed composting facility representatives at 20 MSW composting facilities in Sri Lanka (19 visited in March 2019, 1 visited in January 2020). The composting facilities included represent approximately $16 \%$ of the facilities established under Sri Lanka's Pilisaru Program (Central Environmental Authority, 2012), although a portion of those facilities are currently not in operation. These facilities were located within the districts of Colombo, Galle, Gampaha, Kalutara, and Ratnapura. We selected facilities based on access and location, striving to include both large and small facilities, spanning the urban-to-rural gradient. We obtained permission from local authorities prior to each facility visit. Interviews included a structured questionnaire covering operation parameters including feedstock (amount and sources of biodegradable MSW accepted), configuration and duration of the composting process, finished compost materials (ratio of biodegradable MSW to finished compost, amount of compost produced, compost quality testing), and compost sales. We then asked interviewees to describe past and current challenges, initiating a brief dialogue concerning key factors that hinder or enable success at the facility. We recorded interview responses by hand. 


\section{Compost Quality Analysis}

In preliminary project team meetings and conversations with stakeholders in Sri Lanka, it became evident that uncertainty concerning the quality of MSW compost in Sri Lanka was potentially a critical factor influencing the overall system. Therefore, we assessed compost quality at the same 20 individual MSW composting facilities where we interviewed compost facility representatives. Following interviews, we collected multiple sub-samples of finished compost using a handheld scoop from piles or bags and combined them into a single composite sample for analysis. We stored samples in sealed polyethylene bags within a cooler with ice packs until delivery to the laboratory. To avoid contamination, we washed and disinfected sampling equipment between facilities. Compost samples were analyzed at the Industrial Technology Institute in Colombo for moisture, $\mathrm{pH}$, conductivity, organic carbon, $\mathrm{C}: \mathrm{N}$ ratio, major macronutrients $(\mathrm{N}, \mathrm{P}, \mathrm{K})$, other macronutrients ( $\mathrm{Ca}, \mathrm{Mg}$ ), heavy metals ( $\mathrm{Cd}, \mathrm{Cr}, \mathrm{Hg}, \mathrm{Pb}, \mathrm{Ni}$ ), fecal coliforms, and Salmonella.

\section{Stakeholder Workshops}

We held two stakeholder workshops in Sri Lanka during January 2020, one in Colombo and one in Ratnapura. The Colombo workshop, held at the headquarters of the International Water Management Institute, was attended by 11 representatives from composting facilities visited during this project, 11 additional attendees representing various stakeholder groups (Central Environmental Authority, Department of Agriculture, plantation sector, and NGOs), and project team members. This workshop included a presentation of compost quality results by the lead author, a panel discussion including agricultural sector representatives on compost use, and facilitated roundtable discussions. Additionally, representatives from composting facilities were given an opportunity to provide written answers to the following questions: What are the key problems or challenges that you face at your compost facility? What key solutions have improved your composting operation? For the Ratnapura workshop, 30 individuals in addition to our project team members participated, including 24 stakeholders from the tea sector and 6 academics focused on agriculture in the district. The format of the Ratnapura workshop included a presentation of compost quality results by the lead author followed by a facilitated discussion with participants focused on compost use in the tea sector. Stakeholder workshop discussions were moderated and recorded in written format by the project team, including translation for English and Sinhala. Field notes were coded and grouped by themes.

\section{Data Analysis}

For compost quality data, we determined summary statistics and compared our results to the standards specified in the SLS 1634:2019 standard for compost made from MSW (Sri Lanka Standards Institution, 2019). We also compared our heavy metals results to alternative compost standards from outside of Sri Lanka, which are in some cases more stringent (British Standards Institution, 2011; European Union, 2015). To investigate factors leading to fecal coliform detection in composts, we used logistic regression to model the binary outcome from fecal coliforms testing $(1=$ meets SLS 1634:2019 standard, $0=$ does not meet standard). Our initial model included a binary moisture content predictor $(1=$ meets SLS 1634:2019 standard, $0=$ does not meet standard), C:N ratio (also as binary for meeting standard or not), facility size (i.e., compost produced per month), and composting duration (months). Each of these variables can potentially affect the survival of fecal coliforms in MSW compost (Brinton et al., 2009). We used the $g \operatorname{lm}()$ function in $R$ version 3.6.3 with family set to binomial("logit"), followed by the step() function for stepwise model selection based on the Akaike information criterion (AIC).

In total, approximately 60 individuals participated in this study, in either the semi-structured interviews at composting facilities, a stakeholder workshop, or both. We analyzed data from interviews and stakeholder workshops in multiple ways. First, we quantified some of the qualitative data obtained from composting facilities (e.g., counts for compost markets sold to, challenges faced by composting facilities, solutions identified at composting facilities) (Creswell, 2009). Second, we examined multiple levels in our system and the validity of some information collected (e.g., comparison of quantitative compost analysis with stakeholder perspectives on compost quality and how it affects system success) (Creswell, 2009). Furthermore, we used coding and the constant comparison method to analyze interviews and stakeholder workshop records to build an explanation for what key factors can hinder or facilitate success of Sri Lankan composting systems (Boeije, 2002; Yin, 2009; Metson and Bennett, 2015). We illustrate our results using a causal loop diagram (Nedelciu et al., 2019), including causal links between system components and emphasizing key challenges and solutions identified during interviews and stakeholder workshops. This description of the system, including both direct and indirect links among components, allows identification of different loops and potential cascading effects.

\section{RESULTS}

\section{Characteristics of Composting Facilities Included in Study}

The 20 composting facilities included in this study received 1 to approximately 500 tons ( $\mathrm{t}$ ) of biodegradable MSW feedstock per day. Facility managers reported that the mass of compost produced equaled $19 \pm 7 \%$ of the initial feedstock, equating to $\sim 3$ to $\sim 3,000$ t of compost produced monthly $(<10,10-100,100-$ 1000 , and $>1000$ t compost per month at $8,8,3$, and 1 facilities, respectively). Municipal solid waste feedstocks received came from (in order of decreasing magnitude on average) household kitchen waste, shops and markets, hotels, small restaurants, and other sources (schools, government institutions, factories). Use of animal manure was rare and in small amounts. For example, one facility used cow dung to help balance C:N ratio, but this was greatly limited by cost, while another facility accepted small amounts of residues from poultry slaughter houses. Only one of the 20 facilities accepted human fecal sludge, but this material was processed in a separate parallel 
composting process so that the facility made two compost products: one derived from biodegradable MSW (included in this study) and another that was derived from co-composting of biodegradable MSW and fecal sludge (not included in this study).

The composting process was similar across most facilities (Figure 3), with common practices including: windrow composting with turning every 7-14 days, windrow size of $\sim 1-2 \mathrm{~m}$ tall $\times 1.5 \mathrm{~m}$ wide with variable length, resting periods (e.g., 2 weeks) before or after rotary sieve, and recycling of coarse solids removed by sieve back to new windrows to help control moisture. Total composting duration varied from 1.5 to 4 months (mean $=\sim 3$ months). Finished compost was reportedly tested at a wide range of frequencies (0.5-12 times per year), with testing every 3-4 months being most common. Test indicators commonly mentioned included NPK, pH, fecal coliforms, and heavy metals.

\section{Compost Quality Analysis}

Seventeen MSW compost quality parameters measured for the samples collected in this study $(n=20)$ and included in the SLS 1634:2019 standards (Sri Lanka Standards Institution, 2019) are shown in Table 2. On average ( \pm 1 standard deviation), compost facilities met $78 \pm 9 \%$ of the 17 SLS 1634:2019 standards assessed here $(\min =65 \%, \max =100 \%)$, indicating variable MSW compost quality. Only one facility's compost met all 17 standards. Parameters for which standards were commonly not met included moisture, conductivity, $\mathrm{C}: \mathrm{N}$ ratio, $\mathrm{K}_{2} \mathrm{O}$, and Mg (Table 2). Macronutrients, including N, P, and $\mathrm{K}$, showed relatively wide ranges, indicating that the soil fertility value of these compost materials can likely vary substantially (Table 2 ).

All 20 compost samples met the SLS 1634:2019 standards for heavy metals, which are more lenient than the EU Eco-Label in some cases (European Union, 2015). However, EU Eco-Label standards for heavy metals were also met in all cases except cadmium for six samples (1.1-2.6 mg Cd kg-1). Four of these six samples also failed to meet the cadmium standard in UK PAS100:2011 (British Standards Institution, 2011).

Salmonella was not detected in any compost samples. Fecal coliforms were detected in 9 out of 20 compost samples at counts ranging from 2 to $>100 \mathrm{MPN} / \mathrm{g}$. Any detection of fecal coliforms indicates failure to meet the SLS 1634:2019 standard, which is more stringent than compost standards elsewhere (e.g., EU Eco-Label standard for E. coli is < 1,000 MPN/g; European Union, 2015). In the stepwise logistic regression model to predict the binary outcome from fecal coliforms testing $(1=$ meets SLS 1634:2019 standard, $0=$ does not meet standard), the best model based on AIC included only the binary moisture content predictor $(1=$ meets SLS 1634:2019 standard, $0=$ does not meet standard). In this model, the binary moisture content predictor was significant $(p=0.0333)$. These results indicated that not meeting the SLS 1634:2019 moisture standard (i.e., relatively wet compost with moisture content $>25 \%$ ) increased the odds that the compost did not meet the fecal coliform standard by a factor of 9.33 .

\section{Compost Markets}

The 20 MSW compost facilities sold compost a variety of user types, with the most common being households, tea producers, rice paddy farms, vegetable and/or fruit farms, and flower shops (Figure 4A). Most facilities (75\%) sold compost to 2-3 types of compost users (Figure 4B). Compost was commonly sold in bags (e.g., 2, 5, 10, or $50 \mathrm{~kg}$ ) or loose in bulk for prices ranging from Rs. 5 to 15 per $\mathrm{kg}$ depending on quantity (bag vs. bulk) and facility. Various strategies are being used to market and sell MSW compost, including: onsite plant displays (Figure 3), promotions through agricultural instructors, signs/labels, selling bags onsite, out of nearby stalls, or in government offices, establishing contracts with dealers who distribute to farmers or flower shops, signing agreements with plantations, sourcing material for large

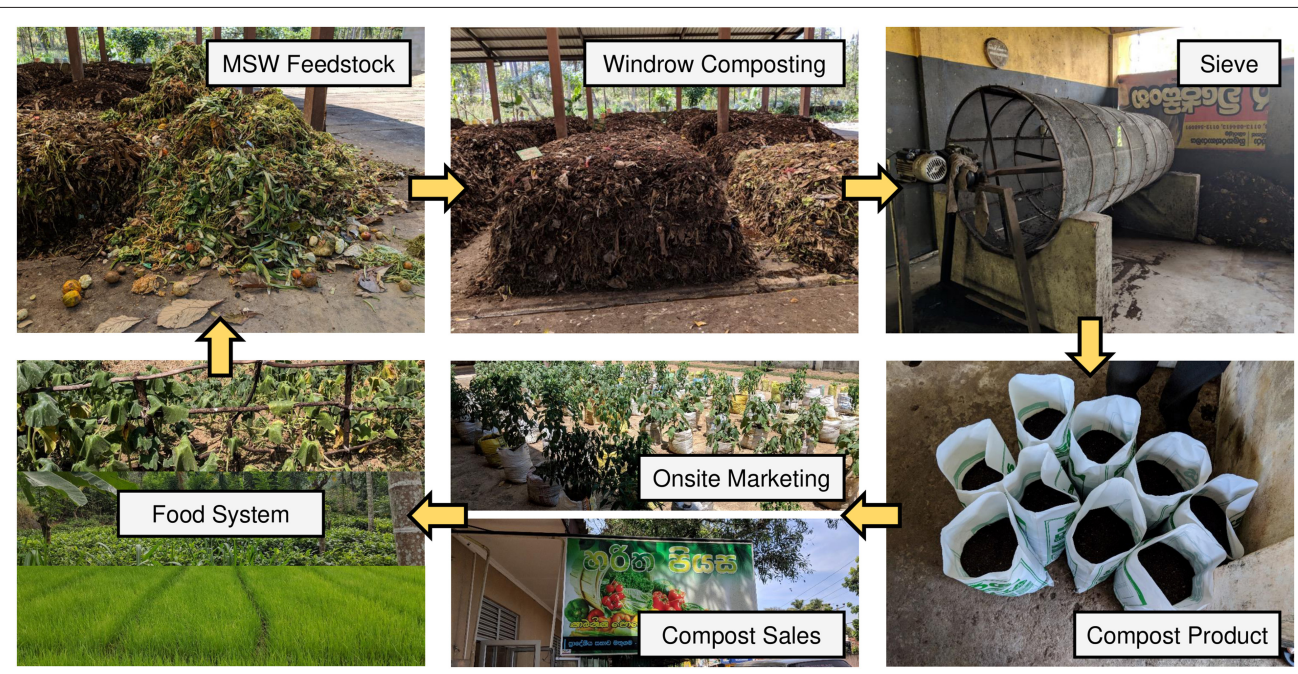

FIGURE 3 | Municipal solid waste (MSW) composting systems in Sri Lanka, illustrating the composting process, marketing/sales, and food system components. All photos by E. Roy. 
TABLE 2 | Compost quality parameters for samples collected from MSW composting facilities in Sri Lanka ( $n=20)$ compared to the SLS 1634:2019 Standards (Sri Lanka Standards Institution, 2019).

\begin{tabular}{|c|c|c|c|c|c|c|c|}
\hline Parameter & Units & Mean \pm standard deviation & Median & Min & Max & SLS 1634:2019 Standard & $\%$ meeting standard \\
\hline \multicolumn{8}{|c|}{ Physical and Chemical Properties } \\
\hline Moisture & $\%$ & $29 \pm 14$ & 27 & 10 & 68 & $\leq 25$ & 50 \\
\hline $\mathrm{pH}$ & - & - & 7.7 & 6.8 & 8.9 & $6.5-8.5$ & 90 \\
\hline Conductivity & $\mathrm{mS} / \mathrm{cm}$ & $6.9 \pm 4.0$ & 7.5 & 0.1 & 16.2 & $\leq 4.0$ & 25 \\
\hline \multicolumn{8}{|c|}{ Organic Matter } \\
\hline Organic C & $\%$ by mass & $35 \pm 11$ & 34 & 16 & 56 & $\geq 20$ & 90 \\
\hline $\mathrm{C}: \mathrm{N}$ & ratio & $22 \pm 7$ & 22 & 12 & 31 & $10-25$ & 60 \\
\hline \multicolumn{8}{|c|}{ Macronutrients } \\
\hline $\mathrm{N}$ & $\%$ by mass & $1.7 \pm 0.5$ & 1.5 & 1.0 & 2.5 & $\geq 1.0$ & 100 \\
\hline $\mathrm{P}_{2} \mathrm{O}_{5}$ & $\%$ by mass & $1.0 \pm 0.3$ & 0.9 & 0.6 & 1.6 & $\geq 0.5$ & 100 \\
\hline $\mathrm{K}_{2} \mathrm{O}$ & $\%$ by mass & $0.9 \pm 0.5$ & 0.8 & 0.2 & 1.8 & $\geq 1.0$ & 40 \\
\hline $\mathrm{Mg}$ & $\%$ by mass & $0.6 \pm 0.8$ & 0.3 & 0.1 & 2.7 & $\geq 0.5$ & 40 \\
\hline $\mathrm{CaO}$ & $\%$ by mass & $1.7 \pm 1.7$ & 1.6 & 0.1 & 7.6 & $\geq 0.7$ & 70 \\
\hline \multicolumn{8}{|c|}{ Heavy Metals } \\
\hline $\mathrm{Cd}$ & $\mathrm{mg} / \mathrm{kg}$ & $0.9 \pm 0.7$ & 0.6 & 0.2 & 2.6 & $\leq 3$ & 100 \\
\hline $\mathrm{Pb}$ & $\mathrm{mg} / \mathrm{kg}$ & $18 \pm 8$ & 17 & 9 & 47 & $\leq 150$ & 100 \\
\hline $\mathrm{Cr}$ & $\mathrm{mg} / \mathrm{kg}$ & $22 \pm 16$ & 19 & 11 & 84 & $\leq 150$ & 100 \\
\hline $\mathrm{Ni}$ & $\mathrm{mg} / \mathrm{kg}$ & $6 \pm 3$ & 7 & Not detected & 11 & $\leq 50$ & 100 \\
\hline $\mathrm{Hg}$ & $\mathrm{mg} / \mathrm{kg}$ & $0.1 \pm 0.1$ & 0.2 & Not detected & 0.3 & $\leq 2$ & 100 \\
\hline
\end{tabular}
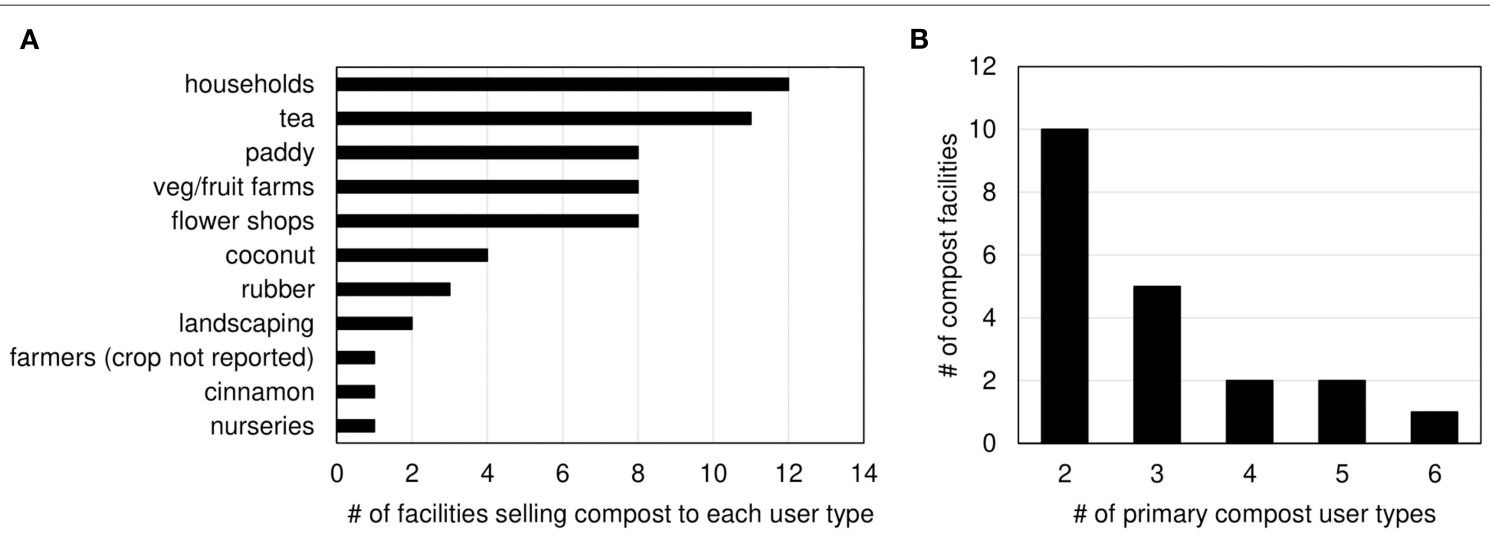

FIGURE 4 | (A) Compost user types purchasing compost from the 20 municipal solid waste (MSW) composting facilities included in this study. (B) Number of primary compost user types for individual MSW composting facilities.

landscaping projects, co-location of organic compost and crop distribution hubs, and offering free transportation. For 8 out 20 facilities (40\%), the amount of compost produced (when processing all biodegradable MSW received) reportedly exceeded demand for their compost product.

\section{Key Challenges and Factors That Support Success}

Composting facility representatives reported numerous challenges (Table 3) and factors that support success (Table 4). During on-site interviews, facility representatives frequently mentioned two challenges: space constraints (12 out of 20 facilities) and insufficient market demand for compost (8 out of 20 facilities). Reported effects of space constraints included reduced capacity for accepting and composting biodegradable MSW, open dumping, limitations on composting duration, windrows located outside of roof cover, and reduced capacity for storing excess compost when market demand is lacking. Reported strategies for dealing with excess compost when market demand is lacking included stockpiling on site (when space is available), delaying compost production to match demand if possible, and providing compost for free to farms or government (when no storage space exists). Written questionnaire results at the Colombo workshop confirmed that space constraints and insufficient market demand are key challenges, while facility representatives also mentioned poor waste separation and lack of technology with relatively high frequency, along with 12 additional challenges (Table 3 ). Challenges mentioned during 
TABLE 3 | Key challenges identified by composting facility representatives in written questionnaires at the Colombo stakeholder workshop.

\begin{tabular}{|c|c|c|c|c|c|c|c|c|c|c|c|c|c|c|c|c|}
\hline 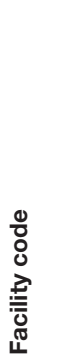 & 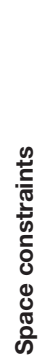 & 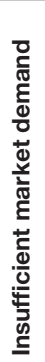 & 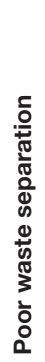 & 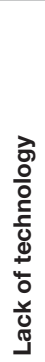 & 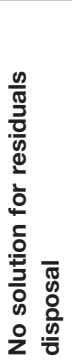 & 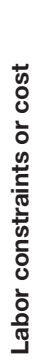 & 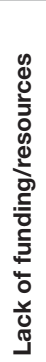 & 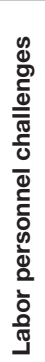 & 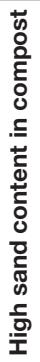 & 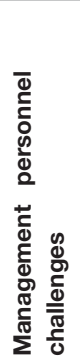 & 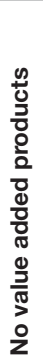 & 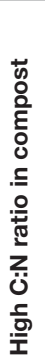 & 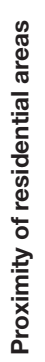 & 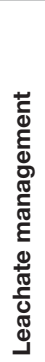 & 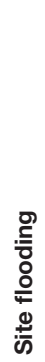 & 흠 \\
\hline$f 1$ & $x$ & $x$ & $x$ & & $x$ & & & & & & & & & & & \\
\hline f2 & & & & & & & & & $x$ & & & & & & & \\
\hline f3 & & $x$ & & $x$ & & & & & & $x$ & $x$ & & & & & \\
\hline $\mathrm{f} 4$ & $x$ & & & $x$ & & $x$ & & & $x$ & & & $X$ & & & & \\
\hline f5 & $x$ & $X$ & $x$ & & & & & & & & & & & & & \\
\hline f6 & $x$ & & & & & & & & & & & & $x$ & $x$ & & \\
\hline $\mathrm{f} 7$ & $x$ & & $x$ & $x$ & & & & $x$ & & & & & & & $x$ & \\
\hline f8 & $x$ & $X$ & & & $x$ & & $x$ & & & & & & & & & \\
\hline f9 & $x$ & $X$ & $x$ & $x$ & $x$ & & $x$ & $x$ & & $x$ & & & & & & $X$ \\
\hline $\mathrm{f} 10$ & $x$ & & & & & $x$ & $x$ & & & & & & & & & \\
\hline $\mathrm{f} 11$ & $x$ & & $x$ & $x$ & & $x$ & & & & & & & & & & \\
\hline Total & 9 & 5 & 5 & 5 & 3 & 3 & 3 & 2 & 2 & 2 & 1 & 1 & 1 & 1 & 1 & 1 \\
\hline
\end{tabular}

TABLE 4 | Key actions taken to solve problems identified by composting facility representatives in written questionnaires at the Colombo stakeholder workshop.

\begin{tabular}{|c|c|c|c|c|c|c|c|c|c|c|c|c|c|c|c|c|}
\hline 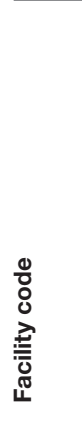 & 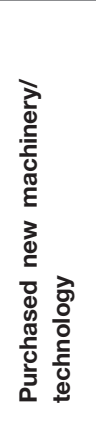 & 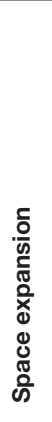 & 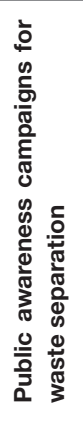 & 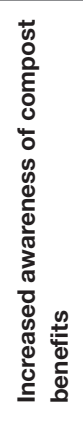 & 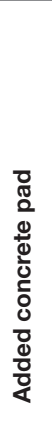 & 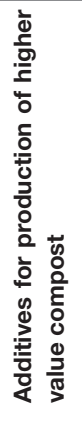 & 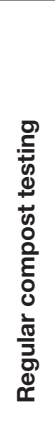 & 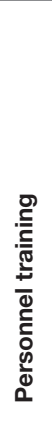 & 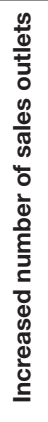 & 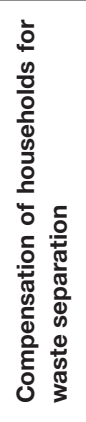 & 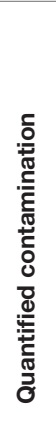 & 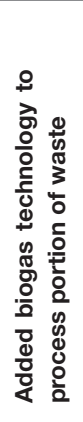 & 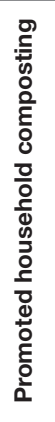 & 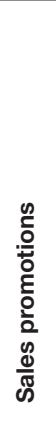 & 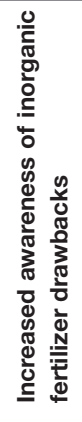 & 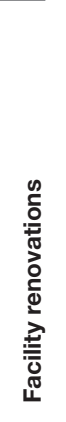 \\
\hline f1 & $x$ & $x$ & & & & & & & & & & & & & & \\
\hline f2 & & & & & $x$ & & & & & & & & & & & \\
\hline f3 & & & & & & $x$ & & & & & & & & & & \\
\hline $\mathrm{f} 4$ & $x$ & $x$ & & & & & $x$ & & & & & & & & & \\
\hline f5 & & $x$ & $x$ & & & & & $x$ & $x$ & & & & & & & \\
\hline f6 & $x$ & & $x$ & & & & & & & $x$ & & & & & & \\
\hline f7 & & $x$ & & & & & & & & & $x$ & $x$ & & & & \\
\hline f8 & & & & $x$ & & & & & & & & & $x$ & & & \\
\hline f9 & & & & $x$ & & & & & & & & & & $x$ & & \\
\hline $\mathrm{f} 10$ & $x$ & & & & & & & & & & & & & & $x$ & \\
\hline $\mathrm{f} 11$ & $x$ & & $x$ & & & & & & & & & & & & & $x$ \\
\hline Total & 5 & 4 & 3 & 2 & 1 & 1 & 1 & 1 & 1 & 1 & 1 & 1 & 1 & 1 & 1 & $\overline{1}$ \\
\hline
\end{tabular}

on-site interviews but not in the written questionnaires at the Colombo workshop included flies, compost consistency, lack of compost testing, marketing, competition with private sector fertilizer companies, and low nutrient content of compost.
Challenges have forced some facilities offline. For example, 9 out of 13 composting facilities in the Galle district that we contacted in March 2019 were reportedly not in operation at that time. 
Agricultural sector representatives shared several important insights during the stakeholder workshops on key challenges limiting successful reuse of composted MSW. First, poor, uncertain, or variable MSW compost quality is reportedly an important factor limiting compost use in agriculture. Specific compost quality concerns expressed included high sand content, high C:N ratio with low $\mathrm{N}$ content (limiting crop yield benefits), odor, pathogens, heavy metals, chemical residues, contamination with inert materials (e.g., glass, plastic), and weed seeds. Second, multiple workshop participants commented on the lack of organized compost testing and certification of composts meeting standards with clear labeling on products. A tea plantation representative commented that compost testing for standards is currently too expensive. Third, agricultural sector workshop participants conveyed that best practices for compost use, including application rates and timing, are not widely known among farmers.

Facility representatives reported a number of actions taken to solve problems and improve their composting operations (Table 4). Solutions mentioned multiple times in written questionnaires completed at the Colombo workshop included purchase of new machinery/technology, space expansion, public awareness campaigns for waste separation, and increased awareness of compost benefits. Twelve additional solutions were reported in the written questionnaires (Table 4). Additional solutions not shown in Table 4 were reported during onsite interviews, including adjustments to tipping fees for biodegradable MSW vs. non-biodegradable MSW, leachate management, expanding roof coverage, and new agreements with buyers of bulk compost in large quantities.

Prospective solutions offered by agricultural sector representatives during the workshops included strategies to reduce uncertainty regarding compost quality, making compost more accessible to farmers through efficient distribution, and increasing compost nutrient content. According to the participants, clear labeling is needed that confirms compost meets SLS standards, provides information on material characteristics (NPK at minimum), and recommends application rates. Two participants, including a tea factory representative, suggested that the National Fertilizer Secretariat be responsible for testing and certifying composts, as they are for inorganic fertilizers. There was widespread agreement among participants in the Ratnapura workshop that tea factories could serve as an intermediate node in the distribution of compost from compost facilities to smallholder tea farmers, a system that is already in place for inorganic fertilizer.

To overcome low nutrient content, stakeholder workshop participants (including agricultural sector and composting facility representatives) suggested mixing additives into MSW compost, such as rock phosphate, treated fecal sludge, partially burned rice husks, urine, or urea. However, one tea plantation representative commented:

\footnotetext{
"If the MSW compost includes fecal sludge, there should be assurances given that no contaminants are present and before use there needs to be an awareness program concerning compost quality
}

for farmers and the neighboring communities. We need to keep tea to a high standard to export."

Participants at the Ratnapura workshop remarked that the combination of inorganic fertilizer and compost can be effective, but also that existing organic certification and associated price premiums restrict mixed-use potential. Another agricultural sector participant suggested combining compost applications with use of N-rich organic fertilizers.

Our case study revealed several important dynamics for Sri Lanka's MSW composting system, spanning the sorting of MSW, composting operations, and the agriculture sector where compost is used (Figure 5). A key reinforcing loop can exist whereby insufficient compost market demand limits resources at composting facilities, which can reinforce technology and labor constraints as well as inadequate physical infrastructure, thereby limiting compost process optimization and reinforcing relatively poor compost quality that detracts buyers. This entire reinforcing loop was not present for most compost facilities, but it was hampering the success of several facilities. Figure 5 also illustrates how both challenges and solutions can have undesirable and desirable cascading effects, respectively. For example, poor waste separation by community members that contaminates MSW feedstocks can ultimately influence compost quality and market demand, as well as environmental pollution. As an example solution, site expansion to alleviate space constraints and add roof cover can possibly improve compost quality (and in turn increase market demand), as well as reduce the risk of environmental pollution. This solution along with others in Figure 5 identified by compost facility representatives and/or agriculture sector stakeholders offer leverage points for continued success or, where needed, positive system transformation. However, key among the solutions in Figure 5 is government policy and funding. Relatedly, political commitment from key government officials (e.g., head of local authority) is critical and can influence workers' motivation and the introduction of proper monitoring systems for composting operations. Despite the existence of a national solid waste management policy, multiple stakeholders expressed concern that a comprehensive policy framework for biodegradable MSW composting in Sri Lanka moving forward is still lacking. Based on this feedback and our observations of the system, it seems that high level policy frameworks need to be complemented by operative guidelines, implementation plans, action plans, and standard operating procedures in order to be effective at the local level (also see Kuruppuge and Karunarathna, 2014).

\section{DISCUSSION}

Our results provide several insights into the influences of compost quality along with institutional, economic, and social factors in Sri Lanka's biodegradable MSW composting system.

\section{Compost Quality}

Several stakeholders participating in this project expressed concerns about the quality of compost derived from biodegradable MSW, echoing concerns stated in the literature 


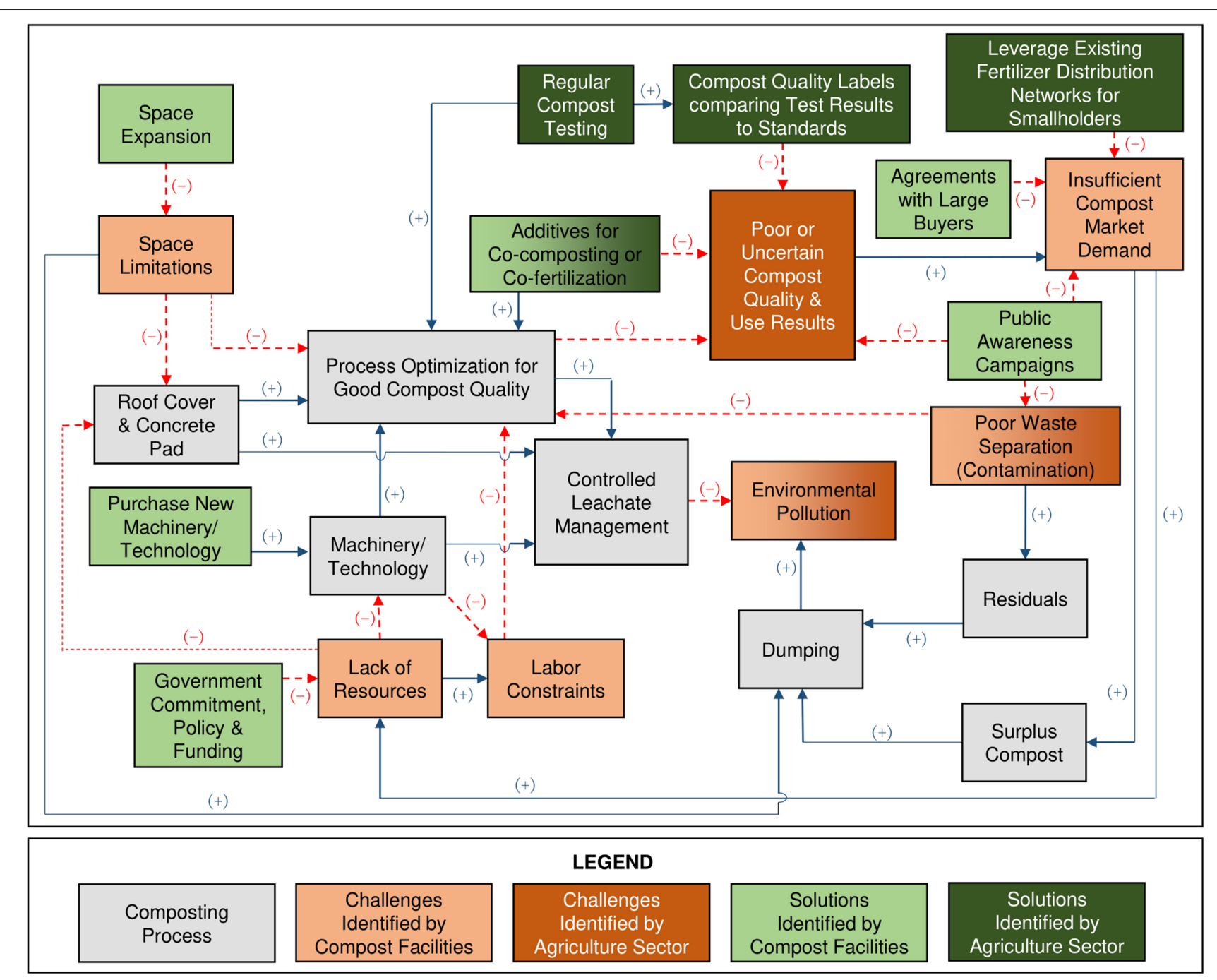

FIGURE 5 | Causal loop diagram showing the main dynamics of MSW compost systems in Sri Lanka as identified from interviews and stakeholder workshops. Color gradients indicate identification by both compost facilities and the agriculture sector. Dotted red arrows with (-) symbol indicate decrease (e.g., lack of resources can decrease roof cover and concrete pad). Solid blue arrows with (+) symbol indicate increase (e.g., regular compost testing can increase process optimization for good compost quality).

(Basnayake and Visvanathan, 2014; Samarasinha et al., 2015; Waqas et al., 2017; Fernando, 2019; Dandeniya and Caucci, 2020). These concerns largely fall into two categories: (1) contamination and (2) limited benefits for crops. Furthermore, our systems analysis helps illustrate how compost quality is pivotal within the overall MSW composting system-a function of program design and implementation, as well as a determinant of value capture in a circular economy (Figure 5).

Of the compost quality parameters tested in this study, the presence of fecal coliforms appears to be the most common contamination risk in Sri Lankan MSW-derived compost products. Fecal coliform tests do not necessarily indicate the presence of pathogenic organisms (Doyle and Erickson, 2006), but previous research has shown strong correlations between the fecal coliform test and specific microorganisms of concern, indicating that it is a useful hygiene indicator (Brinton et al., 2009). We found that the detection of fecal coliforms was more likely when the finished compost was characterized by elevated moisture content. Based on this observation and mechanisms discussed in the literature, we hypothesize that avoiding excess moisture is especially important for pathogen destruction during composting of MSW in Sri Lanka. Biodegradable MSW feedstocks in Sri Lanka are commonly dominated by kitchen waste (e.g., Figure 3), which typically has high moisture content (Kumar et al., 2010). Optimum moisture content of about $60 \%$ should be maintained for effective composting in the windrow method (Weerasinghe et al., 2017). Excess moisture can decrease oxygen penetration into windrow piles, resulting in the development of anaerobic zones following a period of fast degradation (Richard et al., 2002). This in turn decreases 
rates of microbial respiration and possibly the likelihood of uniformly high temperatures required for pathogen destruction (Bernal et al., 2017). Additionally, pathogen regrowth might occur in immature compost when biomass has not been degraded well (Bernal et al., 2017). Options for adjusting moisture content (and in turn $\mathrm{O}_{2}$ availability) during MSW composting include adjusting the feedstock recipe (e.g., inclusion of bulking agents), changing the frequency of windrow turning, altering windrow size, or providing roof cover to limit addition of water to windrows during rain events (Bernal et al., 2017). Implementation of aeration technology could possibly be useful in some cases, with the added benefit of reduced labor cost (De Silva and Yatawara, 2017), but might be prohibitively expensive to install and maintain in other cases. Experimental research is needed in Sri Lanka to better elucidate the effects of these potential management strategies on MSW compost moisture dynamics and fecal coliform detection. The ability to make such changes in practice depends on the availability of resources (e.g., access to feedstock ingredients, labor to turn piles, space and financial support required for roof construction, aeration technology, or alternative windrow management schedules). Moisture management via optimized aeration can also be an important odor prevention measure (Wei et al., 2017).

Our compost quality results indicate that heavy metals are not a common contamination risk for MSW-derived composts in Sri Lanka based on existing standards (Table 2). The only potential exception is cadmium (Cd), which exceeded UK and EU standards for four and six facilities, respectively, but not the less stringent Sri Lankan standard. Research in India has shown that use of MSW compost in tea cultivation can increase tea yield, but also the total Cd concentrations in soil and plant parts. However, average daily intake levels of $\mathrm{Cd}$ through tea infusion suggested no health hazard (Karak et al., 2018). Future risk management efforts should include both efforts to achieve better source separation of biodegradable materials in MSW prior to composting, as well as monitoring of Cd and other heavy metals in soils receiving repeated applications of MSW compost over time (Wei et al., 2017; Karak et al., 2018).

The Sri Lanka MSW compost standard specifies that composts be free of visible non-biodegradable materials except sand (Sri Lanka Standards Institution, 2019). Sieving of finished compost helps facilities meet this requirement despite foreign matter (especially plastic) present in the MSW feedstocks (Dandeniya and Caucci, 2020). However, this standard and other existing ones do not necessarily guarantee that composts are free of microplastics, or other pollutants of emerging concern (Dandeniya and Caucci, 2020; Gui et al., 2021). There has been very limited research on pollutants of emerging concern in composts around the world, including in Sri Lanka. Future studies of MSW composting in Sri Lanka are needed to assess risk posed by organic pollutants and bio-aerosols, microplastics, and antibiotic resistance determinants (when feedstocks include animal manure or fecal sludge) (Dandeniya and Caucci, 2020; Thakali and MacRae, 2021). Routine monitoring of compost quality is already prohibitively expensive in Sri Lanka according to some stakeholders, so it is likely unrealistic to expect pollutants of emerging concern to be routinely monitored in compost products in addition to the existing standards. However, risk assessment studies and continued efforts to improve source separation of biodegradable MSW are important next steps to ensure compost safety.

Stakeholders from multiple sectors commented that limited benefits of MSW composts for crop yield is a key impediment to greater use of this material for soil management in Sri Lankan agriculture. We observed generally low macronutrient nutrient levels in the composts tested, especially $\mathrm{K}, \mathrm{Mg}$, and $\mathrm{Ca}$, which frequently were below the required levels in Sri Lanka Standard SLS 1634:2019 (Table 2). In cases where composting is performed without roof cover in the tropics, intense rainfall events can potentially result in nutrient leaching (Faverial et al., 2016). High C:N ratios exceeding the upper limit of 25 in the Sri Lanka standard for $40 \%$ of composts tested in this study indicate that $\mathrm{N}$ fertilization effects will likely be limited by $\mathrm{N}$ immobilization in these cases (Amlinger et al., 2003). Kitchen waste feedstocks typically have a low C:N ratio (Adhikari et al., 2008). Therefore, our observations of finished composts derived in large part from kitchen waste with high $\mathrm{C}: \mathrm{N}$ ratios suggest substantial $\mathrm{N}$ loss during composting, which can result from rapid mineralization of $\mathrm{N}$ and subsequent ammonia volatilization (Jiang et al., 2011), or potentially leaching (Faverial et al., 2016). N loss as ammonia and potentially other organic N-based compounds can also be a primary source of odor during MSW composting, along with carbon- and sulfur-based compounds (Wei et al., 2017). Odor has been highlighted in other nations (Meyer-Kohlstock et al., 2015), in previous assessments in Sri Lanka (Samarasinha et al., 2015; Dandeniya and Caucci, 2020), and by some stakeholders in this study as a key problem in the MSW composting system, illustrating another connection between technical aspects of composting and human perceptions of the overall system. More research is needed in Sri Lanka to identify effective and economic options for (1) feedstock ingredients for co-composting with MSW, and (2) materials for co-application with MSW compost to soils to improve the fertility value of MSW-derived compost.

Electrical conductivity was the standard least frequently met for the composts analyzed, with 15 out of 20 having values greater than the upper limit $\left(4 \mathrm{mS} \mathrm{cm}^{-1}\right)$ in Sri Lanka Standard SLS 1634:2019 (Table 2). Others have also observed elevated conductivity values in organic amendments derived from food waste and biodegradable MSW (O'Brien et al., 2020; SilesCastellano et al., 2020). For example, researchers in Spain reported high conductivity ( $>10 \mathrm{mS} \mathrm{cm}^{-1}$ ) in MSW composts, which they linked to poor seed germination (Siles-Castellano et al., 2020). Many soluble salts are nutrients beneficial to plants, while $\mathrm{Na}^{+}$and $\mathrm{Cl}^{-}$are of particular concern for phytotoxicity, soil salinity, and soil sodicity (Gondek et al., 2020). However, there is little agreement on how to classify salts in organic amendments and what, if any, limits should be set (Brinton, 2000), as the negative influence of soluble salts in compost depends on the specific soluble salts present, salt tolerance of the plant species, and whether the compost is blended with soil or other media (Gondek et al., 2020). The Sri Lankan standard is in line with recommendations available in the United States. For example, the University of Maine Soil Testing Lab in the US recommends that final compost blends with soil or container 
media/potting mixes have conductivity values $<4 \mathrm{mS} \mathrm{cm}^{-1}$. Compost characterized by a high conductivity can be mixed with soils or other materials to ensure that it does not cause salt stress to plants and instead enhances crop yields (Gondek et al., 2020). Additionally, bulking agents can be used during composting to reduce conductivity in the overall feedstock (Gondek et al., 2020). Experimental investigations are needed to examine the effects of repeated applications of MSW compost to salt-affected soils, especially in drought-prone areas (Meena et al., 2019). Germination tests can be used in combination with conductivity measurements to better proxy potential phytotoxicity (SilesCastellano et al., 2020).

\section{Institutional, Economic, and Social Factors}

Based on our results and prior literature (Samarasinha et al., 2015; Fernando, 2019; Dandeniya and Caucci, 2020), there are clearly several key institutional, economic, and social factors that influence success, and lack thereof, within Sri Lanka's national biodegradable MSW composting system. According to composting station managers, failure to allocate adequate space and resources during composting program design and implementation can create cascading negative effects throughout the composting system, ultimately limiting compost quality, environmental protection, and public perceptions (Figure 5). However, poor management of composting stations can also create similar challenges (e.g., unsorted waste builds up, reducing usable space)-and further work is needed to understand the relative roles of design vs. management in causing space constraints. Space constraints are difficult to overcome in areas of high population density and very limited open land, especially in and around Colombo. Additionally, financial barriers, as well as ineffective program management, can exacerbate challenges in compost production by limiting access to technology, labor, and markets (Fernando, 2019). For example, during an interview with government officials in one location where the composting facility had recently been closed, we learned that a broken rotary sieve had precipitated the failure of the entire facility. Funds were not available to replace the machine, and local laborers were unable to fix it, so the composting operation ceased. Lack of financial management is a broader challenge beyond this one example. Most compost plants are unable to ringfence the revenues that they generate as the funds are all pooled into a larger municipal revenue/funds bucket which then gets "lost." We therefore recommend that municipalities ringfence revenues so that they are able to allocate funds for repairs, etc., when needed.

In some cases, compost operators have adapted to space and resource constraints in ways that can degrade compost quality and create risks for human health and the environment, including composting outside of roof cover, reducing composting duration, and accepting less material which inevitably increases open dumping. Therefore, the intended goals of sanitation, resource recovery, and environmental protection can only be achieved with adequate financial investment, continued facility support, careful site planning, good operational and monitoring practices, good market linkages, political commitment, and local expertise. A stronger national policy is critical to facilitating the allocation of required funds from the central government to local authorities, creating a better regulatory environment for solid waste management, and establishing supportive organizations (Fernando, 2019).

Additionally, more emphasis on compost market development is needed to enable success (i.e., sustainability of compost plants generally). Eight out of 20 facilities included in this study were unable to find adequate markets for their compost products. Furthermore, stakeholders from the tea sector indicated that poor or uncertain compost quality is likely to depress compost demand. Ensuring high compost quality is key to establishing and maintaining markets and therefore a stronger national policy would include support for public awareness campaigns to improve source separation of biodegradable MSW, regular compost testing informed by the scientific community, accurate labeling by a respected entity (e.g., National Fertilizer Secretariat), support for acquiring additional feedstocks to use in co-composting that results in a higher quality product, and the aforementioned support at facilities to remove constraints on optimal compost processing. Furthermore, it is essential in program design and implementation to facilitate connections between compost suppliers and potential buyers. This could include support for marketing efforts, making connections between composting facilities and the plantation sector, or leveraging existing fertilizer distribution networks to make MSW compost accessible to smallholders. The Ministry of Agriculture could play a role through their extensive extension programs in educating farmers on the benefits of compost use, which extend beyond the provisioning of nutrients (Bernal et al., 2017). Policy that makes organic fertilizers more competitive on the market-whether it is a subsidy program for organic fertilizers or a program that requires farmers to purchase a certain quantity of organic fertilizer in order to "cash-out" the subsidy of inorganic fertilizers-is also important. Currently, there are plans to form an organic fertilizer authority and provide compost/manure under the fertilizer subsidy scheme. In the recent fertilizer subsidy scheme, only inorganic fertilizer has been provided, which distorts the fertilizer market and leads to low demand for compost, especially when it comes to paddy and other commercial crops.

Finally, a stronger national policy would also provide better incentives and safety provisions for the required labor force (Fernando, 2019). Silberg et al. (2013) provide some evidence from Guatemala that net profits for MSW composting fell when inexpensive unskilled labor was used. Future research should rigorously investigate the potential connections between compost quality, program success, composting operation management structure, pay and incentives for laborers, and on-site environmental health and safety.

\section{Conclusions}

Our analysis shows how institutional, economic, social, and biophysical aspects of the MSW composting system in Sri Lanka are interrelated, where challenges and solutions can create undesirable and desirable cascading effects, respectively. This creates the potential for facility failure and unintended consequences. Compost quality is pivotal within the overall 
MSW composting system-a function of program design and implementation, as well as a determinant of value capture in a circular economy. We observed variable compost quality based on existing standards, with high moisture content, high conductivity, high C:N, low macronutrients, and presence of fecal coliforms being the most common indicators of poor compost quality. However, many composts did largely exhibit high quality based on the parameters tested and current standards, so broad generalizations about MSW compost quality in Sri Lanka are not possible, creating uncertainty for potential compost buyers. Our analysis confirms many of the challenges suggested in previous studies, including past case studies of food waste composting systems outside of Sri Lanka (Table 1), such as improper waste sorting, poor or uncertain compost quality, and insufficient compost market demand and financial resources. We also identified several key solutions that can enhance the sustainability of biodegradable MSW composting operations in Sri Lanka. These include public awareness campaigns to improve waste separation, adequate funding and space for composting operations, use of additional feedstocks for cocomposting to improve compost quality, regular compost testing and comparison to standards, emphasis on market development, and leveraging of existing fertilizer distribution networks. We recommend that these solutions also be explored in other locations outside of Sri Lanka, especially those having similar composting system challenges, MSW characteristics, and economic conditions. More emphasis on improving compost quality and establishing reliable compost markets is critical for success in efforts to establish sustainable circular foodnutrient systems.

\section{DATA AVAILABILITY STATEMENT}

The datasets presented in this study can be found in online repositories. The names of the repository/repositories and accession number(s) can be found below: https://figshare.com/ articles/dataset/Sri_Lanka_Compost_Characteristics_March_ 2019_/9337481.

\section{ETHICS STATEMENT}

The studies involving human participants were reviewed and approved by Committees on Human Subjects Serving the

\section{REFERENCES}

Adhikari, B. K., Barrington, S., Martinez, J., and King, S. (2008). Characterization of food waste and bulking agents for composting. Waste Manage. 28, 795-804. doi: 10.1016/j.wasman.2007.08.018

Al-Sari, M., Sarhan, M. A. A., and Al-Khatib, I. (2018). Assessment of compost quality and usage for agricultural use: a case study of Hebron, Palestine. Environ. Monit. Assess. 190, 223. doi: 10.1007/s10661-018-6610-X

Amlinger, F., Götz, B., Dreher, P., Geszti, J., and Weissteiner, C. (2003). Nitrogen in biowaste and yard waste compost: dynamics of mobilisation and availability-a review. Eur. J. Soil Biol. 39, 107-116. doi: 10.1016/S1164-5563(03)00026-8

Basnayake, B. F. A., and Visvanathan, C. (2014). "Solid waste management in Sri Lanka," in Municipal Solid Waste Management in Asia and the Pacific
University of Vermont and the UVM Medical Center. Written informed consent for participation was not required for this study in accordance with the national legislation and the institutional requirements.

\section{AUTHOR CONTRIBUTIONS}

ER: conceptualization, data curation, formal analysis, funding acquisition, investigation, methodology, project administration, resources, supervision, validation, visualization, writing-original draft, and writing-review and editing. ME: conceptualization, investigation, methodology, and writing-review and editing. NJ: investigation, methodology, and writing-review and editing. MO: investigation, resources, supervision, and writing-review and editing. CK: conceptualization, funding acquisition, investigation, resources, supervision, and writing-review and editing. IW: investigation and writing-review and editing. MF-C: investigation, visualization, and writing-review and editing. All authors contributed to the article and approved the submitted version.

\section{FUNDING}

We acknowledge funding support from the University of Vermont Office for the Vice President of Research REACH program, awarded to ER and CK. The Fulbright Scholar Program provided funding to $\mathrm{ME}$ and to $\mathrm{CK}$ for his initial research into the effects of climate change on agricultural communities. Open access fees are covered by professional development funds available to ER.

\section{ACKNOWLEDGMENTS}

We thank Pay Drechsel of the International Water Management Institute (IWMI) for his feedback on elements of this project, and Lauren Bomeisl for assistance with Figure 1.

\section{SUPPLEMENTARY MATERIAL}

The Supplementary Material for this article can be found online at: https://www.frontiersin.org/articles/10.3389/fsufs. 2021.748391/full\#supplementary-material

Islands, eds A. Pariatamby and M. Tanaka (Singapore: Springer), 299-316. doi: 10.1007/978-981-4451-73-4_15

Beillard, M. J., and Galappattige, A. (2021). Sri Lanka Restricts and Bans the Import of Fertilizers and Agrochemicals. Global Agricultural Information Network, Report Number CE2021-0007, Foreign Agricultural Service, United States Department of Agriculture.

Bekchanov, M., and Mirzabaev, A. (2018). Circular economy of composting in Sri Lanka: opportunities and challenges for reducing waste related pollution and improving soil health. J. Clean. Prod. 202, 1107-1119. doi: 10.1016/j.jclepro.2018.08.186

Bernal, M. P., Alburquerque, J. A., and Moral, R. (2009). Composting of animal manures and chemical criteria for compost maturity assessment. A review. Bioresour. Technol. 100, 5444-5453. doi: 10.1016/j.biortech.2008.11.027 
Bernal, M. P., Sommer, S. G., Chadwick, D., Qing, C., Guoxue, L., Michel, J.r., et al. (2017). Current approaches and future trends in compost quality criteria for agronomic, environmental, and human health benefits. Adv. Agron. 144, 143-233. doi: 10.1016/bs.agron.2017.03.002

Boeije, H. (2002). A purposeful approach to the constant comparative method in the analysis of qualitative interviews. Qual. Quant. 36, 391-409. doi: 10.1023/A:1020909529486

Brinton, W. F. (2000). Compost Quality Standards and Guidelines. Final Report by Woods End Research Laboratories for the New York State Association of Recyclers.

Brinton, W. F., Storms, P., and Blewett, T. C. (2009). Occurrence and levels of fecal indicators and pathogenic bacteria in market-ready recycled organic matter composts. J. Food Protect. 72, 332-339. doi: 10.4315/0362-028X-72.2.332

British Standards Institution (2011). PAS 100:2011 - Specification for Composted Materials.

Central Environmental Authority (2012). Database of Solid Waste in Sri Lanka. Pilisaru National Solid Waste Management Programme, Ministry of Environment and Renewable Energy, Sri Lanka.

Chen, Y. T. (2016). A cost analysis of food waste composting in Taiwan. Sustainability 8, 1210. doi: 10.3390/su8111210

Climate Change Secretariat (2016). National Adaptation Plan for Climate Change in Sri Lanka. Ministry of Mahaweli Development and Environment, Sri Lanka.

Cordell, D., Dominish, E., Esham, M., Jacobs, B., and Nanda, M. (2021). Adapting food systems to the twin challenges of phosphorus and climate vulnerability: the case of Sri Lanka. Food Secur. 13, 477-492. doi: 10.1007/s12571-020-01118-8

Creswell, J. W. (2009). Research Design: Qualitative, Quantitative, and Mixed Methods Approaches, 3rd Edn. Los Angeles, CA: SAGE.

Dandeniya, W. S., and Caucci, S. (2020). "Composting in Sri Lanka: policies, practices, challenges, and emerging concerns," in Organic Waste Composting through Nexus Thinking, eds H. Hettiarachchi, S. Caucci, and K. Schwärzel (Cham: Springer), 61-89. doi: 10.1007/978-3-030-36283-6_4

Danso, G., Drechsel, P., Fialor, S., and Giordano, M. (2006). Estimating the demand for municipal waste compost via farmers' willingness to pay in Ghana. Waste Manage. 26, 1400-1409. doi: 10.1016/j.wasman.2005. 09.021

De Silva, S., and Yatawara, M. (2017). Assessment of aeration procedures on windrow composting process efficiency: a case study on municipal solid waste in Sri Lanka. Environ. Nanotechnol. Monit. Manag. 8, 169-174. doi: 10.1016/j.enmm.2017.07.008

Doyle, M. P., and Erickson, M. C. (2006). Closing the door on the fecal coliform assay. Microbe 1, 162-163. doi: 10.1128/microbe.1.162.1

European Union (2015). Revision of the EU Ecolabel Criteria for Soil Improvers and Growing Media. Luxembourg: Publications Office of the European Union. doi: $10.2791 / 54696$

Faverial, J., Boval, M., Sierra, J., and Sauvant, D. (2016). End-product quality of composts produced under temperate and tropical climates using different raw materials: a meta-analysis. J. Environ. Manage. 183, 909-916. doi: 10.1016/j.jenvman.2016.09.057

Fernando, R. L. S. (2019). Solid waste management of local governments in the Western Province of Sri Lanka: an implementation analysis. Waste Manage. 84, 194-203. doi: 10.1016/j.wasman.2018.11.030

Gondek, M., Weindorf, D. C., Thiel, C., and Kleinheinz, G. (2020). Soluble salts in compost and their effects on soil and plants: a review. Compost Sci. Util. 28, 59-75. doi: 10.1080/1065657X.2020.1772906

Gui, J., Sun, Y., Wang, J., Chen, X., Zhang, S., and Wu, D. (2021). Microplastics in composting of rural domestic waste: abundance, characteristics, and release from the surface of macroplastics. Environ. Pollut. 274, 116553. doi: 10.1016/j.envpol.2021.116553

Hanjra, M. A., Lydecker, M., Drechsel, P., and Paul, J. (2018). "Ruralurban food and nutrient dynamics and nutrient recovery from waste in developing countries," in Routledge Handbook of Landscape and Food, eds J. Zeunert and T. Waterman (New York, NY: Routledge), 344-365. doi: 10.4324/9781315647692-24

Idris, A., Inanc, B., and Hassan, M. N. (2004). Overview of waste disposal and landfills/dumps in Asian countries. J. Mater. Cycles Waste Manag. 6, 104-110. doi: 10.1007/s10163-004-0117-y

Jiang, T., Schuchardt, F., Li, G., Guo, R., and Zhao, Y. (2011). Effect of C/N ratio, aeration rate and moisture content on ammonia and greenhouse gas emission during the composting. J. Environ. Sci. 23, 1754-1760. doi: 10.1016/S1001-0742(10)60591-8

JICA (2016). Data Collection Survey on Solid Waste Management in Democratic Socialist Republic of Sri Lanka. Japan International Cooperation Agency.

Karak, T., Abollino, O., Paul, R. K., Dutta, A. K., Giacomino, A., Khare, P., et al. (2018). Achievability of municipal solid waste compost for tea cultivation with special reference to cadmium. CLEAN-Soil Air Water 46, 1800093. doi: 10.1002/clen.201800093

Kaza, S., Yao, L. C., Bhada-Tata, P., and Van Woerden, F. (2018). What a Waste 2.0: A Global Snapshot of Solid Waste Management to 2050. Urban Development. Washington, DC: World Bank. Available online at: https://openknowledge. worldbank.org/handle/10986/30317 (accessed July 1, 2021).

Keng, Z. X., Chong, S., Ng, C. G., Ridzuan, N. I., Hanson, S., Pan, G. T., et al. (2020). Community-scale composting for food waste: a life-cycle assessment supported case study. J. Clean. Prod. 261, 121220. doi: 10.1016/j.jclepro.2020. 121220

Kumar, M., Ou, Y. L., and Lin, J. G. (2010). Co-composting of green waste and food waste at low C/N ratio. Waste Manage. 30, 602-609. doi: 10.1016/j.wasman.2009.11.023

Kuruppuge, R. H., and Karunarathna, A. K. (2014). "Issues in management of municipal solid waste: Institutional capacity of local authorities in Sri Lanka." in Proceedings of the $4^{\text {th }}$ International Conference on Solid Waste Management, eds Waste Management and Resource Utilization (Limassol). doi: 10.13140/2.1.4102.7841

Lasardi, K., Protopapa, I., Kotsou, M., Pilidis, G., Manios, T., and Kyriacou, A. (2006). Quality assessment of composts in the Greek market: the need for standards and quality assurance. J. Environ. Manage. 80, 58-65. doi: 10.1016/j.jenvman.2005.08.011

Meadows, D. H. (2008). Thinking in Systems: A Primer. White River Junction: Chelsea Green Publishing.

Meena, M. D., Yadav, R. K., Narjary, B., Yadav, G., Jat, H. S., Sheoran, P., et al. (2019). Municipal solid waste (MSW): strategies to improve salt affected soil sustainability: a review. Waste Manage. 84, 38-53. doi: 10.1016/j.wasman.2018.11.020

Metson, G., and Bennett, E. (2015). Facilitators and barriers to organic waste and phosphorus re-use in Montreal. Element. Sci. Anthrop. 3, 1-13. doi: 10.12952/journal.elementa.000070

Meyer-Kohlstock, D., Schmitz, T., and Kraft, E. (2015). Organic waste for compost and biochar in the EU: mobilizing the potential. Resources 4, 457-475. doi: $10.3390 /$ resources 4030457

National Policy on Solid Waste Management. (2007). Ministry of Environment and Natural Resources. Colombo.

Nedelciu, C. E., Ragnarsdóttir, K. V., and Stjernquist, I. (2019). From waste to resource: a systems dynamics and stakeholder analysis of phosphorus recycling from municipal wastewater in Europe. Ambio 48, 741-751. doi: 10.1007/s13280-018-1097-9

Niles, M. (2020). Majority of rural residents compost food waste: policy and waste management implications for rural regions. Front. Sustain. Food Syst. 3, 123. doi: 10.3389/fsufs.2019.00123

O'Brien, B. J., Neher, D. A., and Roy, E. D. (2020). Nutrient and pathogen suppression properties of anaerobic digestates from dairy manure and food waste feedstocks. Waste Biomass Valori. 11, 6565-6573. doi: 10.1007/s12649-019-00906-4

Otoo, M., and Drechsel, P. (2018). Resource Recovery from Waste: Business Models for Energy, Nutrient and Water Reuse in Low-and Middle-Income Countries. Oxon: Routledge. doi: 10.4324/9781315 780863

Pariatamby, A., and Fauziah, S. H. (2014). "Sustainable 3R practice in the Asia and Pacific Regions: the challenges and issues," in Municipal solid waste management in Asia and the Pacific Islands, eds A. Pariatamby and M. Tanaka (Singapore: Springer) 15-40. doi: 10.1007/978-981-4451-73-4_2

Pilisaru National Solid Waste Management Program. (2008). Ministry of Environment \& Natural Resources. Sri Lanka.

Richard, T. L., Hamelers, H. V. M., Veeken, A., and Silva, T. (2002). Moisture relationships in composting processes. Compost Sci. Util. 10, 286-302. doi: 10.1080/1065657X.2002.10702093

Roy, E. D. (2017). Phosphorus recovery and recycling with ecological engineering: a review. Ecol. Eng. 98, 213-227. doi: 10.1016/j.ecoleng.2016.10.076 
Samarasinha, G. G. D. L.W., Bandara, M. A. C. S., and Karunarathna, A. K. (2015). Municipal Solid Waste Composting: Potentials and Constraints - HARTI Research Report No: 174. Colombo: Hector Kobbekaduwa Agrarian Research and Training Institute.

Silberg, T., Murphrey, T. P., Wingenbach, G., and Lombardini, L. (2013). Exploring the profitability of compost micro-enterprises in Chimaltenango, Guatemala: a case study of business sustainability for international development. J. Int. Agric. Ext. Educ. 20, 58-70. doi: 10.5191/jiaee.2013.20305

Siles-Castellano, A. B., López, M. J., López-González, J. A., Suárez-Estrella, F., Jurado, M. M., Estrella-González, M. J., et al. (2020). Comparative analysis of phytotoxicity and compost quality in industrial composting facilities processing different organic wastes. J. Clean. Prod. 252, 119820. doi: $10.1016 /$ j.jclepro.2019.119820

Sri Lanka Standards Institution (2019). SLS 1634:Compost Made from Municipal Solid Waste.

Thakali, A., and MacRae, J. D. (2021). A review of chemical and microbial contamination in food: what are the threats to a circular food system? Environ. Res. 194, 110635. doi: 10.1016/j.envres.2020.110635

van Zon, L., and Siriwardena, N. (2000). Garbage in Sri Lanka: An Overview of Solid Waste Management in the Ja-Ela Area. Colombo: Integrated Resources Management Program in Wetlands.

Waqas, M., Nizami, A. S., Aburiazaiza, A. S., Barakat, M. A., Rashid, M. I., and Ismail, I. M. I. (2017). Optimizing the process of food waste compost and valorizing its applications: a case study of Saudi Arabia. J. Clean. Prod. 176, 426-438. doi: 10.1016/j.jclepro.2017.12.165

Weerasinghe, V. P. A., Kaluarachchi, U., and Pilapitiya, S. (2017). Resource conservation by effective composting of municipal solid waste in Sri Lanka - optimum moisture range for the bio-oxidative phase. Int. J. Waste Resour. 7, 313. doi: $10.4172 / 2252-5211.1000313$
Wei, Y., Li, J., Shi, D., Liu, G., Zhao, Y., and Shimaoka, T. (2017) Environmental challenges impeding the composting of biodegradable municipal solid waste: a critical review. Resour. Conserv. Recy. 122, 51-65. doi: 10.1016/j.resconrec.2017.01.024

Yin, R. K. (2003). Case Study Research: Design and Methods, Vol. 5. Thousand Oaks, CA: Sage.

Yin, R. K. (2009). "How to do better case studies," in The SAGE Handbook of Applied Social Research Methods, $2^{\text {nd }}$ Edn., eds L. Bickman and D. J. Rog (Thousand Oaks, CA: Sage), 254-282. doi: 10.4135/9781483348 858.n8

Conflict of Interest: The authors declare that the research was conducted in the absence of any commercial or financial relationships that could be construed as a potential conflict of interest.

Publisher's Note: All claims expressed in this article are solely those of the authors and do not necessarily represent those of their affiliated organizations, or those of the publisher, the editors and the reviewers. Any product that may be evaluated in this article, or claim that may be made by its manufacturer, is not guaranteed or endorsed by the publisher.

Copyright (c) 2021 Roy, Esham, Jayathilake, Otoo, Koliba, Wijethunga and Fein-Cole. This is an open-access article distributed under the terms of the Creative Commons Attribution License (CC BY). The use, distribution or reproduction in other forums is permitted, provided the original author(s) and the copyright owner(s) are credited and that the original publication in this journal is cited, in accordance with accepted academic practice. No use, distribution or reproduction is permitted which does not comply with these terms. 